\title{
ERRATUM
}

\section{Putative fasciclin-like arabinogalactan-proteins (FLA) in wheat (Triticum aestivum) and rice (Oryza sativa): identification and bioinformatic analyses}

\author{
Ahmed Faik · Jaouad Abouzouhair · \\ Fathey Sarhan
}

Published online: 17 October 2006

(C) Springer-Verlag 2006

Erratum to: Mol Genet Genomics 276:478-494

DOI 10.1007/s00438-006-0159-z

Unfortunately, the last sentence of the Acknowledgments was missing. It is provided here:

This work was supported in part by a Genome Canada and Genome Quebec grant to F.S.

The online version of the original article can be found at http://dx.doi.org/10.1007/s00438-006-0159-z.

A. Faik $(\bowtie)$

Department of Environmental and Plant Biology,

Ohio University, Porter Hall, Athens, OH 45701, USA

e-mail: faik@ohio.edu

J. Abouzouhair · F. Sarhan

Département des sciences biologiques,

Université du Québec à Montreal (UQAM),

141 Président Kennedy, H2X 3 Y5 Montreal, QC, Canada 